\title{
Filamentous fungi occurrence on Molossus molossus (Pallas, 1766) (Chiroptera: Molossidae) present in an Atlantic Forest remnant in Southern Brazil
}

\author{
B. G. Furtado (D), G. D. Savi ${ }^{a *}$ (D), E. Angioletto ${ }^{a}$ (D) and F. Carvalho ${ }^{b}$ \\ ${ }^{a}$ Universidade do Extremo Sul Catarinense - UNESC, Programa de Pós-graduação em Ciência e Engenharia de Materiais, \\ Laboratório de Desenvolvimento de Biomateriais e Materiais Antimicrobianos - LADEBIMA, Criciúma, SC, Brasil

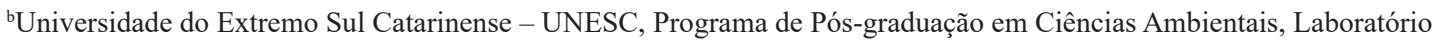 \\ de Zoologia e Ecologia de Vertebrados - LABZEV, Criciúma, SC, Brasil \\ *e-mail: geovanasavi@gmail.com
}

Received: March 20, 2020 - Accepted: May 26, 2020 - Distributed: November 30, 2021

(With 2 figures)

\begin{abstract}
The bats usually inhabit shelters with favorable conditions for fungal proliferation, including pathogenic and opportunistic species. The fungal diversity present on bats is little known and the studies are scarce in Brazil, which only a work has been performed in Cerrado and Pantanal biomes. Therefore, the objective of this study was evaluating the occurrence of filamentous fungi on the rostral region of Molossus molossus in an Atlantic Forest remnant of Brazil. The bats were captured with mist nets installed outside a shelter located in the municipality of Treviso, (28 $29^{\prime} 23^{\prime \prime} \mathrm{S}$ and $\left.49^{\circ} 31^{\prime} 23^{\prime \prime} \mathrm{W}\right)$, south region of state Santa Catarina. With a swab sterile moistened in saline solution, samples from the rostral region were obtained from all captured M. molossus individuals. The samples were taken to the laboratory for analysis and isolation in different culture media, followed of identification of fungal through the microculture technique. In total, 15 individuals were captured, which five fungal genus and 19 taxa were identified. Among the taxa registered, Aspergillioides sp.2, (47\%), Penicillium sp.1 (33\%), Chrysonilia sp. (33\%), Cladosporium sp. (27\%) were classified as little constant. In terms of abundance, Penicillium sp.1 (34\%), Aspergillioides sp.2 (21\%) and Aspergillus sp.2 (11\%) were the most abundant in the samples. The results showed the occurrence of high diversity fungal in the rostral region of M. molossus in the Atlantic Forest, which is higher than observed in others Brazilian biomes. Some fungal genera found may harbor pathogenic and opportunistic species that need to be identified for preventing potential disease well as for bat conservation projects.
\end{abstract}

Keywords: bat-fungus relationships, fungal infections, microbiology.

\section{Ocorrência de fungos filamentosos em Molossus molossus (Pallas, 1766) (Chiroptera: Molossidae) presentes em um remanescente da Mata Atlântica no Sul do Brasil}

\begin{abstract}
Resumo
Os morcegos comumente abrigam-se em locais com condições favoráveis para proliferação fúngica, incluindo espécies patogênicas e oportunistas. A diversidade fúngica presente nos morcegos é pouco conhecida e os estudos são escassos no Brasil, no qual apenas um trabalho tem sido realizado nos biomas do Cerrado e Pantanal. Portanto, o objetivo deste estudo foi avaliar a ocorrência de fungos filamentosos na região rostral de Molossus molossus em um remanescente da Mata Atlântica no sul do Brasil. Os morcegos foram capturados com redes-de-neblina instaladas na saída de um

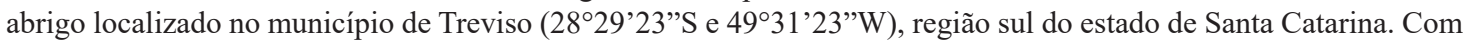
um swab esterilizado e umedecido em solução salina, amostras da região rostral foram obtidas de todos os indivíduos de M. molossus capturados. As amostras foram levadas ao laboratório para análise e isolamento em diferentes meios de cultura, seguido de identificação taxonômica fúngica pela técnica de microcultivo. No total, 15 indivíduos foram capturados, nos quais 5 gêneros fúngicos e 19 taxa foram identificados. Dentre os taxa registrados foram classificados como pouco constante Aspergillioides sp.2, (47\%), Penicillium sp.1 (33\%), Chrysonilia sp. (33\%), Cladosporium sp. (27\%). Em termos de abundância, Penicillium sp.1 (34\%), Aspergillioides sp.2 (21\%) e Aspergillus sp.2 (11\%) foram os mais abundantes nas amostras. Os resultados mostraram ocorrência de elevada riqueza de fungos na região rostral de M. molossus na Mata Atlântica, riqueza essa que é superior àquela observada para outros biomas brasileiros. Alguns gêneros fúngicos encontrados podem abrigar espécies patogênicas e oportunistas que precisam ser identificadas tanto para prevenir potenciais doenças, assim como, para os projetos de conservação dos morcegos.
\end{abstract}

Palavras-chave: relações fungo-morcegos, infecções fúngicas, microbiologia. 


\section{Introduction}

In the last two decades, there was an increase in the number of infectious diseases spread in the world, which among others factors, may be caused by pathogens agents transmitted by different host (Heitman, 2011; Fisher et al., 2012), including some fungal species. Fungal pathogens affect both animals and plants, leading to death and in more severe cases, a local extinction of populations (Fisher et al., 2012). Emerging infectious diseases caused by fungal species can affect terrestrial, freshwater and marine environments, with potential to cause outbreaks (epizoonotic) or even affecting populations on global scales (panzootic) (Daszak et al., 2001). The International Union for Conservation of Nature (IUCN) report that of the 833 endangered species, $4 \%$ (31) were related to infectious diseases (Fisher et al., 2012). Mycoses have becoming one of the leading threats to wildlife with potential to reduce population of diverse taxa including sea corals, snakes, lizards, turtles and amphibians (Shapiro et al., 2015).

For example, a recent study reports that fungal infections in eggs of tegu lizards Salvator merianae (Duméril \& Bilbron, 1839) can cause damage and death of their embryos (Carvalho et al., 2020). Moreover, a study performed by Santana-Neto et al. (2010) showed that filamentous fungi may have a role in the regulation of field scorpion populations. These were isolated from Tityus stigmurus (Thorell, 1876) and the infected individuals had their behavior modified by reducing feeding and locomotion, in addition, none of the infected individuals survived.

Diverse types of the shelters utilized by bats, constitute favorable environments for the spread of fungi, and have great interaction with pathogenic agents (Tencate et al., 2012). Dermatophytes, filamentous fungi and opportunist yeast have already been previously reported in fecal samples and nasal hairs of bats (Tencate et al., 2012; Shapiro et al., 2015). Some pathogens have the potential to spread and devastate more susceptible populations as the case of White Nose Syndrome (WNS) (Blehert et al., 2008), a disease reported in various bats species (Foley et al., 2011; Turner et al., 2011). White Nose Syndrome is caused by the fungus Pseudogymnoascus destructans (Ascomycota) (Minnis and Lindner, 2013) and it was considered a deadly epidemic in some parts of the United States and Canada, causing the death of about one million bats (Frick et al., 2010).

Due to growing number of infectious diseases, studies have been conducted on opportunist mycoses in bats in Brazil. In Rondônia, a study aimed to isolate Malassezia spp. from the acoustic meatus from a total of 30 bats, where Malassezia spp. were isolated in $80 \%$ of the Molossus molossus (Pallas, 1766) studied (Gandra et al., 2008). In the other hand, in bats captured in São Paulo, fungi isolated of gastrointestinal tract showed the presence mainly Aspergillus sp. (29\%), Microsporum sp. (6\%) and Penicillium sp. (6\%), Tricophyton sp. (4\%) and zygomycetes (4\%) and Fusarium sp. (2\%) (Tencate et al., 2012).
In recent study, Histoplasma capsulatum was observed in spleen and liver of $M$. molossus collected in urban areas of São Paulo (Paz et al., 2018). This interaction between bats and fungi is extremely complex and, therefore, their understanding is essential of species biology and ecology, as well as a tool for conservation and environmental health programs. In general, the records of interaction between bats and fungi were made in temperate regions, whereas in other areas under tropical and subtropical climate influence, there are not knowledge about these interactions.

Bats are important in natural environment due to their high food plasticity, as insect species controllers, pollinators and dispersers (Fleming et al., 1972), interacting with numerous environmental elements (Bernard and Fenton, 2007) and still has an important role in ecosystem dynamics (Kalko, 1998; Bernard, 2001). Currently, about 1,384 species have been described worldwide (Taylor and Tuttle, 2019), of which 182 species found in Brazil (Nogueira et al., 2018), and at least 50 species with confirmed records in Santa Catarina state (Passos et al., 2010; Carvalho and Fabián, 2011; Cherem and Althoff, 2015; Carvalho et al., 2017; Althoff et al., 2018).

In Santa Catarina, Molossidae has 10 species recorded (Passos et al., 2010; Carvalho et al., 2017; Althoff et al., 2018), which includes the specie M. molossus, evaluated in the present study. These bats are medium size insectivores characterized by present rounded ears and close to the midline above the head, hair dark brown to reddish brown and a ventral tuft of hair on the upper lip (Weber et al., 2013; Reis et al., 2017). It is considered a synanthropic species, occurring often in urban areas where the human constructions are used as a shelter (Souza, 2011; Reis et al., 2012; Talamoni et al., 2013). In Neotropical bats, especially Brazilian species, it is unknown about the microbiota associate with these animals, which only a single work (Shapiro et al., 2015) has been done so far. The possibility of fungi associated to $M$. molossus are diverse and may vary between individuals, however, the studies are scarce in Brazil (Shapiro et al., 2015). Considering the reasons stated above, the objective of this study was to describe the mycobiota from $M$. molossus species in an Atlantic Forest remnant in Southern Brazil.

\section{Material and Methods}

\subsection{Study site}

The present study was conducted in the municipality of Treviso (28 29'23'S and 49³1'23”W), southern Santa Catarina (Figure 1). The region is inserted in the Atlantic Forest biome, in an area of Submontane Dense Ombrophylous Forest (IBGE, 2012). According to Köppen's classification, the region's climate is Cfa type, humid mesothermal without defined dry season (Alvares et al., 2013). The bat colony was located in a small house inside ceiling (about $4.5 \mathrm{~m}$ from the ground), not inhabited, which are little used by the local community. 

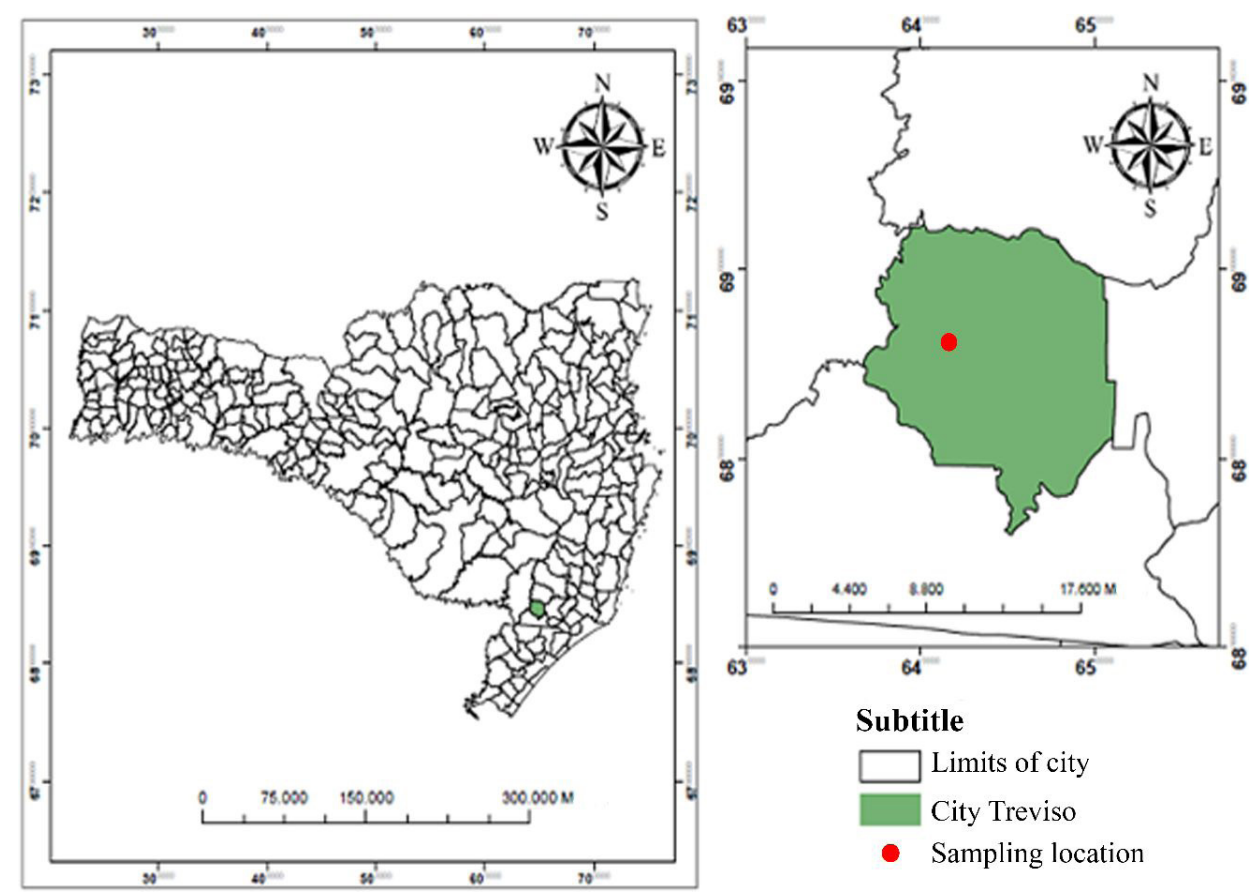

Figure 1. Study area showing the location of Treviso municipality in the Southern state of Santa Catarina, and in detail, the delimitation of the city and the site where the individuals of $M$. molossus were sampled.

\subsection{Bat capture and sample collection}

Bats were captured in mist nets (Peracchi and Nogueira, 2010), installed near of the shelter exit. The bats were placed in cloth bags and taken to identification to species level according to Gregorin and Taddei (2002) and Díaz et al. (2016).

The sample of rostral region of each bat was obtained through of a swab sterile moistened in saline solution. The swab was lightly spread on surface of the bat rostral region (ABNT, 2018) and added in a tube with $1 \mathrm{~mL}$ of $0.9 \%$ sterile saline solution. The samples were taken to the laboratory for analysis and isolation in different culture media, followed of identification of fungal species through the microculture technique. Culture plates were also exposed for $15 \mathrm{~min}$ near at the same bat capture sites. The procedure was carried out to quantify and identify the fungi in this environment and so, to avoid attributing contaminating fungi to bats.

After obtaining the samples, all bats were release at the same capture sites. The study was carried out under license from SISBIO (53718-1) and approval by the Committee of Ethical for use of animals in experiments from Universidade do Extremo Sul Catarinense (065/2018-1).

\subsection{Fungi identification}

The tube containing the swab were vigorously agitated and an aliquot of each sample was spread on the surface of potato dextrose agar (PDA) with drigalski spreader (Silva et al., 2010; Tortora et al., 2012). Then, the medium PDA was incubated at $27{ }^{\circ} \mathrm{C} \pm 2{ }^{\circ} \mathrm{C}$ in the dark for seven days. The results were presented taking into account the colony count and the strains were examined for genus identification.

The fungi colonies were previously identified according to macromorphological characteristics (for example: cotton, velvety, and powdery textures), pigmentation and colony size (Pitt and Hocking, 2009). The isolated strains were sub-cultured on malt extract agar (MEA), 25\% glycerol nitrate agar (GN25) and czapek yeast extract agar (CYA) media and again incubated at $27{ }^{\circ} \mathrm{C} \pm 2{ }^{\circ} \mathrm{C}$ by seven days. Then, the microculture technique was used to aid the identification of fungal genera. The fungi were grown between three to five days in a temperature of $27^{\circ} \mathrm{C} \pm 2{ }^{\circ} \mathrm{C}$ and afterward, they were examined under a light microscope $(100 \times$ and $400 \times$ magnifications) and genera identification was carried out according to available taxonomic keys and guides (Raper and Fennel, 1965; Pitt, 1979; Nelson et al., 1983; Frisvad et al., 2004; Samson et al., 2006; Pitt and Hocking, 2009).

\subsection{Data analysis}

The analysis of the fungi composition was performed according to taxa number identification, which was attributed as specific richness. The frequency of taxa was also calculated, being that each bat was considered as a sample. For this reason, the following formula was used: sample number, which was reported the fungal type, divided by the total number of samples (bats), multiplied by 100 to obtain a percentage. The taxa were classified as rare category (frequency below than $25 \%$ ), little constant (frequency greater than $25.1 \%$ and less than $50 \%$ ) and constant (frequency greater than $50.1 \%$ ). 
Finally, the relative abundance of each taxa fungi in the sample was calculated using the colonies number as an abundance metric.

\section{Results}

From the 15 samples analysed, 19 fungal growth belonging to five genus, and 19 taxa were identified in rostral region of M. molossus (Table 1, Figure 2). Among the taxa registered, Aspergillioides sp. 2,(47\%), Penicillium sp. 1(33\%), Chrysonilia sp. (33\%), Cladosporium sp. (27\%) were classified as little constant, being the others taxa included in the rare category (Table 1). It is important to highlight that none of the taxa analyzed was considered constant. In terms of abundance, Penicillium sp. 1 (34\%), Aspergillioides sp. 2 (21\%) and Aspergillus sp. 2 (11\%) were the most abundant in the samples. Culture plates exposed near to the bats capture sites showed unimpressive fungi growth, in average $<1.0 \times 10^{1} \mathrm{CFU} / \mathrm{mL}$.

\section{Discussion}

A high fungal richness was associated with the rostral region of M. molossus in an Atlantic Forest remnant. If compared to Cerrado and Pantanal, the taxa number is $61 \%$ higher than these environments for the same bat specie (Shapiro et al., 2015). Despite of the study of
Shapiro et al. (2015) to be the only work with this approach in Brazil, the environmental studied which may influence in the specific richness of the fungi. The Atlantic Forest is a biome with higher humidity when compared to Cerrado and Pantanal, for example. Climatic parameter as temperature and humidity affect the survival (Kokurewicz et al., 2016) and fungal dispersal capacity (IOM, 2011). Considering that tropical environments are those that has highest diversity of fungi (Maia, 2005) is possible that this also occur in the Atlantic Forest.

However, if compared only the taxa number reported, studies performed in others regions as Australia, North America and Italy described a higher number than observed in the current study - up to 149 taxa (Voyron et al., 2011; Johnson et al., 2013; Kokurewicz et al., 2016; Holz et al., 2018), which would contradict that tropical areas tend to have higher fungal richness. Therefore, other factors may be related as the sampling in different parts of bat body, carcass collection, number of individuals and environmental samples, as performed in the studies mentioned above.

Among the taxa registered, Aspergillioides sp. 2, (47\%), was classified as little constant, however, it is the most frequent in relation to the classification of other taxa identified in the current study. This is a subgenus of Penicillium, which was also the most frequent observed in M. molossus in the

Table 1. Genera identification, relative frequency and relative abundance of fungal taxa found in the rostral region of M. molossus in an Atlantic Forest remnant in Southern Brazil.

\begin{tabular}{|c|c|c|c|c|c|c|}
\hline Taxa & Id. ${ }^{1}$ & $\mathbf{N}^{2}$ & $\mathbf{R F}^{3}(\%)$ & Index & $\begin{array}{c}\text { Colony } \\
\text { number }\end{array}$ & $\operatorname{RA}^{4}(\%)$ \\
\hline \multicolumn{7}{|l|}{ Genus Aspergillus } \\
\hline Aspergillus sp.1 & 1.0 & 1 & 7 & Rare & 1 & 0.6 \\
\hline Aspergillus sp.2 & 1.1 & 2 & 13 & Rare & 18 & 11 \\
\hline Aspergillus sp.3 & 1.2 & 2 & 13 & Rare & 2 & 1 \\
\hline Circumdati sp.1 & 1.3 & 1 & 7 & Rare & 1 & 0.6 \\
\hline Circumdati sp.2 & 1.4 & 1 & 7 & Rare & 2 & 1 \\
\hline Fumigati sp.1 & 1.5 & 1 & 7 & Rare & 2 & 1 \\
\hline \multicolumn{7}{|l|}{ Genus Penicillium } \\
\hline Aspergillioides sp.1 & 2.0 & 3 & 20 & Rare & 9 & 5 \\
\hline Aspergillioides sp.2 & 2.1 & 7 & 47 & Little constant & 35 & 21 \\
\hline Aspergillioides sp.3 & 2.2 & 1 & 7 & Rare & 4 & 3 \\
\hline Aspergillioides sp.4 & 2.3 & 1 & 7 & Rare & 1 & 0.6 \\
\hline Aspergillioides sp.5 & 2.4 & 2 & 13 & Rare & 3 & 2 \\
\hline Penicillium sp.1 & 2.5 & 5 & 33 & Little constant & 60 & 34 \\
\hline Penicillium sp.2 & 2.6 & 1 & 7 & Rare & 2 & 1 \\
\hline Penicillium sp.3 & 2.7 & 1 & 7 & Rare & 7 & 4 \\
\hline Furcatum sp.1 & 2.8 & 1 & 7 & Rare & 2 & 1 \\
\hline Furcatum sp.2 & 2.9 & 1 & 7 & Rare & 2 & 1 \\
\hline \multicolumn{7}{|l|}{ Genus Chrysonilia } \\
\hline Chrysonilia sp. & 3.0 & 5 & 33 & Little constant & 12 & 7 \\
\hline \multicolumn{7}{|l|}{ Genus Cladosporium } \\
\hline Cladosporium sp. & 4.0 & 4 & 27 & Little constant & 4 & 3 \\
\hline \multicolumn{7}{|l|}{ Genus Moniliella } \\
\hline Moniliella sp. & 5.0 & 1 & 7 & Rare & 1 & 0.6 \\
\hline
\end{tabular}

${ }^{1}$ Identification; ${ }^{2}$ number; ${ }^{3}$ relative frequency; ${ }^{4}$ relative abundance. 

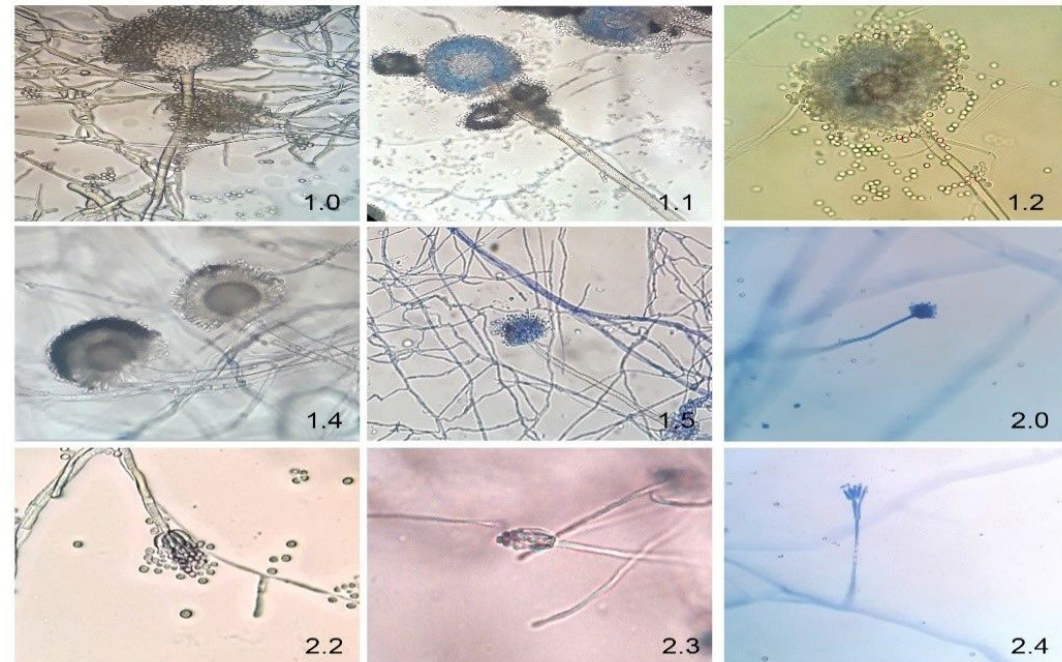

1.2
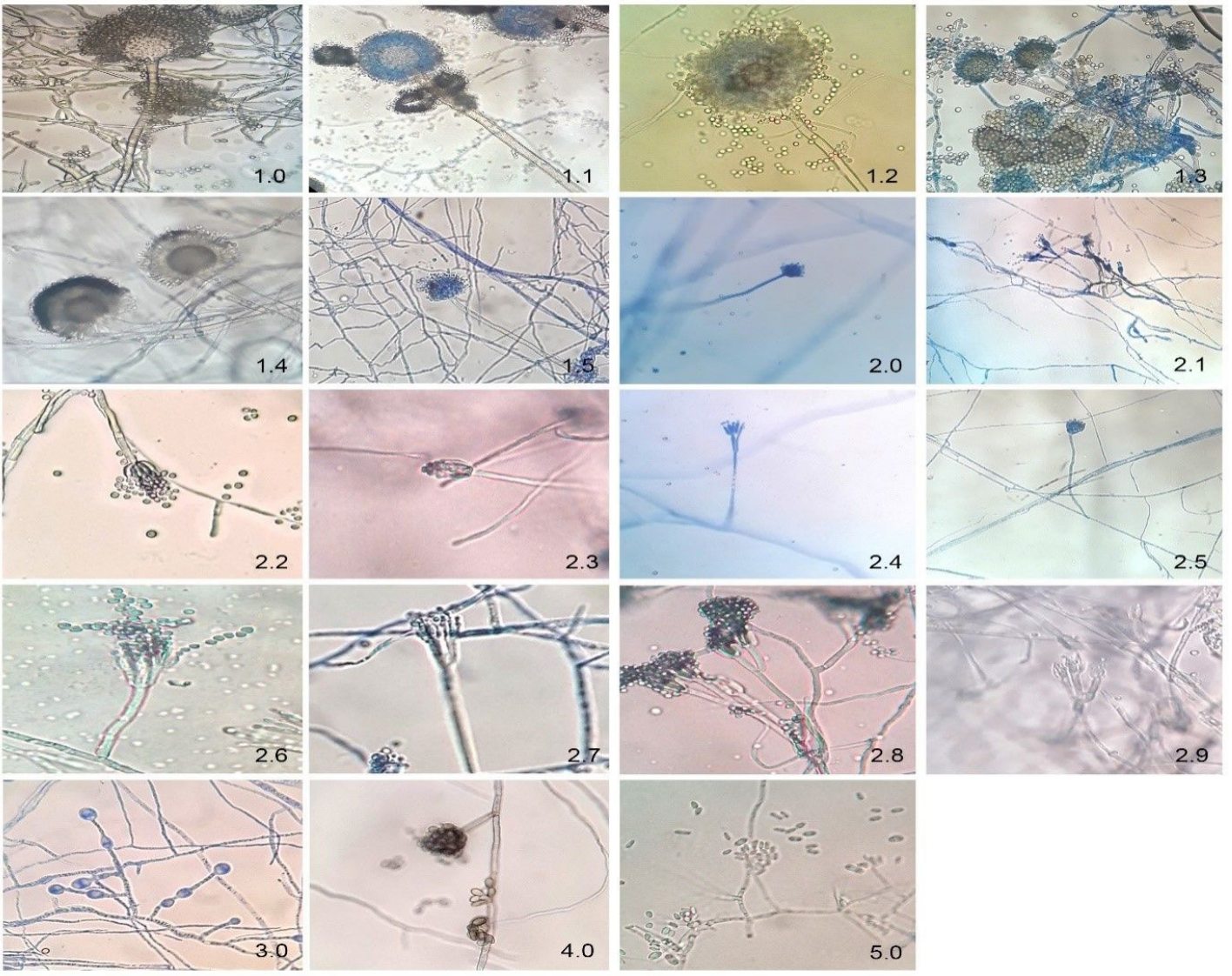

Figure 2. Optical microscopy of 400x magnification showing isolated and identified filamentous fungi of the rostral region of M. molossus after growth in microcultive, according to indicate in the Table 1 for each genus and subgenus (3-day incubation).

Cerrado and Pantanal areas (Shapiro et al., 2015). It is a fungus considered as ubiquitous, opportunistic and saprophyte (Pitt and Hocking, 2009). Moreover, Penicillium is the most common fungi in various environmental compartments as soil, air, and extreme environments, considering a wide range of physicochemical parameters, as temperature, $\mathrm{pH}$ and salinity variations (Yadav et al., 2018; Pitt and Hocking, 2009). In addition, it is possible highlight that some fungi as Penicillium spp. or Cladosporium spp. colonize a wide variety of bat shelters (Shapiro et al., 2015), which would explain its high frequency.

In the Cerrado and Pantanal biomes there was no report of isolated fungi pathogenic to bats (Shapiro et al., 2015), however, some species found in this study as Aspergillus terreus, Cladosporium and Paecilomyces may cause opportunistic infections in horses, domestic dogs, alligator, crocodiles, chameleons, sea turtle (Foley et al., 2002) and humans (Perfect and Schell, 1996; Woolhouse and Gowtage-Sequeria, 2005).

The genus Aspergillus has potential to infect host as plants, insects, birds, and mammals, being considered a umbrella term that covers a wide range of diseases as mycose and mycotoxicoses, along with allergies, immune system dysfunction, internal organ infections, as well inflammation of retina, peritoneum, lungs, and urethral system (Seyedmousavi et al., 2015; Kokurewicz et al., 2016). Considering that M. molossus is a synanthropic bat species, the Aspergillus sp. found in this bat should be constantly studied since that some species are pathogenic to humans (Kwon-Chung and Sugui, 2013; Seyedmousavi et al., 2015). In our study, both genera Aspergillus and Cladosporium were found in M. molossus.

The variability of species richness and composition of fungi, even among individuals of the same bat species and within a small geographic area, points to a potentially complex and species-rich mycobiota associated with bat (Shapiro et al., 2015). Moreover, the tropical microfungi remain unexplored in the Brazilian biomes (Maia, 2005). The Atlantic Forest is an example of this, even with a large part of Brazilian populations and numerous research centers, it is lesser known biome (Maia, 2005) and the current scenario of degradation and alteration of this biome become this situation still more worrying. Considering the pathogenic potential of some fungi taxa, it is important to know the local diversity of each organism group within Atlantic Forest, providing subsidies for preservation and prevention strategies in order to avoid the spread and introduction of pathogenic organisms in 
the natural environment (Maia, 2005; Fisher et al., 2012; Shapiro et al., 2015).

\section{Conclusion}

Molossus molossus had a richness mycobiota of filamentous fungi associated with the rostral region. The total number of taxa reported was above that observed in others Brazilian biomes; however, this should be carefully analyzed, since these data may be influenced by sampling methods and climate conditions, for instance. The taxa Aspergillioides were the most frequent of the genus Penicillium. Despite that fungi species with pathogenic potential were not identified in the bats, the genus Aspergillus deserve highlight herein why can cause serious health problems to animals and human.

The mycobiota associate to bats from Atlantic Forest is still recent; however, due to alteration of the natural environments, further studies are necessary. In this case, it is suggested that other bats (beyond insectivorous) be sampled as frugivores, nectarivores, and sanguivores. The study on interactions between fungi and bats provide important data for species conservation and especially future threats to fauna.

\section{Acknowledgements}

We would like to thank the "Laboratório de Zoologia e Ecologia de Vertebrados" for facilitating the collection of bats and to the "Laboratório de Desenvolvimento de Biomateriais e Materiais Antimicrobianos" for facilitating the sample processing and fungi identification. This work was supported by the "Fundação de Amparo à Pesquisa e Inovação do Estado de Santa Catarina" under Grant [2017TR1706].

\section{References}

ASSOCIAÇÃO BRASILEIRA DE NORMAS TÉCNICAS ABNT, 2018 [viewed 6 December 2018]. INT 300: Instrução para coleta em superficie e Exposição Ambiental. 1. ed. Rio de Janeiro: ABNT [online]. Available from: http://www.drpio.com. br/labalimentos/files/3e 740e0c3fb2be957754c7c96543d73d.pdf

ALTHOFF, S., CARVALHO, F., FERNANDES LIMA LUCIANO, B., GARCIA, J. and STANKE, A., 2018. First record of Molossops neglectus for the state of Santa Catarina. Check List, vol. 14, no. 1, pp. 167-172. http://dx.doi.org/10.15560/14.1.167.

ALVARES, C.A., STAPE, J.L., SENTELHAS, P.C., GONÇALVES, J.L.M. and SPAROVEK, G., 2013. Köppen's climate classification map for Brazil. Meteorologische Zeitschrift, vol. 22, no. 6, pp. 711-728. http://dx.doi.org/10.1127/0941-2948/2013/0507.

BERNARD, E. and FENTON, M.B., 2007. Bats in a fragmented landscape: species composition, diversity and habitat interactions in savannas of Santarém, Central Amazonia, Brazil. Biological Conservation, vol. 134, no. 3, pp. 332-343. http://dx.doi. org/10.1016/j.biocon.2006.07.021

BERNARD, E., 2001. Vertical stratification of bat communities in primary forests of Central Amazon, Brazil. Journal of Tropical
Ecology, vol. 17, no. 1, pp. 115-126. http://dx.doi.org/10.1017/ S0266467401001079.

BLEHERT, D., HICKS, A., BEHR, M., METEYER, C., BERLOWSKI-ZIER, B., BUCKLES, E., COLEMAN, J., DARLING, S., GARGAS, A., NIVER, R., OKONIEWSKI, J., RUDD, R. and STONE, W., 2008. Bat white-nose syndrome: An emerging fungal pathogen? Science, vol. 323, no. 5911, pp. 227 227. http://dx.doi.org/10.1126/science.1163874. PMid:18974316.

CARVALHO, A.M., SOUZA, L.K.H., ATAÍDES, F.S. and PÉRES JUNIOR, A.K., 2020. Eggs of tegu lizard, Salvator merianae (Duméril \& Bilbron, 1839) (Squamata; Teiidae) damaged by fungal infections. Brazilian Journal of Biology $=$ Revista Brasileira de Biologia, vol. 80, no. 1, pp. 112-114. http://dx.doi. org/10.1590/1519-6984.193388. PMid:31166370.

CARVALHO, F., BÔLLA, D., PATEL, F., MIRANDA, J., ALTHOFF, S. and ZOCCHE, J.J., 2017. Ampliação de distribuição de Eumops Patagonicus (Chiroptera: Molossidae) e primeiro registro em ambiente de Restinga na Costa Leste do Brasil. Mastozoología Neotropical, vol. 24, no. 2, pp. 443-450.

CARVALHO, F. and FABIÁN, M.E., 2011. Mammalia, Chiroptera, Phyllostomidae, Platyrrhinus recifinus (O. Thomas, 1901): First confirmed record in the state of Santa Catarina, Southern Brazil. Check List, vol. 7, no. 2, pp. 139-141. http://dx.doi. org/10.15560/7.2.139.

CHEREM, J.J. and ALTHOFF, S.L., 2015. Mamíferos de uma área de estepe ombrófila nos estados de Paraná e Santa Catarina, Sul do Brasil. Boletim da Sociedade Brasileira de Mastozoologia, vol. 73 , pp. $42-50$

DASZAK, P., CUNNINGHAM, A.A. and HYATT, A.D., 2001. Anthropogenic environmental change and the emergence of infectious diseases in wildlife. Acta Tropica, vol. 78, no. 2, pp. 103-116. http://dx.doi.org/10.1016/S0001-706X(00)00179-0. PMid:11230820

DÍAZ, M.M., SOLARI, S., AGUIRRE, L.F., AGUIAR, L.M.S. and BARQUEZ, R.M., 2016. Clave de identificacion de los murcielagos de Sudamerica. Publication Especial N² 2. Tucumán, Argentina: PCMA (Programa de Conservación de lós Murciélagos de Argentina), $160 \mathrm{p}$.

FISHER, M.C., HENK, D.A., BRIGGS, C.J., BROWNSTEIN, J.S., MADOFF, L.C., MCCRAW, S.L. and GURR, S.J., 2012. Emerging fungal threats to animal, plant and ecosystem health. Nature, vol. 484, no. 7393, pp. 186-194. http://dx.doi.org/10.1038/ nature10947. PMid:22498624.

FLEMING, T.H., HOOPER, E.T. and WILSON, D.E., 1972. Three central american bat communitis: structure, reproductive cycles, and movement patterns. Ecology, vol. 53, no. 4, pp. 555569. http://dx.doi.org/10.2307/1934771.

FOLEY, J.E., NORRIS, C.R. and JANG, S.S., 2002. Paecilomycosis in dogs and horses and a review of the literature. Journal of Veterinary Internal Medicine, vol. 16, no. 3, pp. 238-243. http:// dx.doi.org/10.1111/j.1939-1676.2002.tb02363.x. PMid:12041651.

FOLEY, J., CLIFFORD, D., CASTLE, K., CRYAN, P. and OSTFELD, R.S., 2011. Investigating and managing the rapid emergence of white-nose syndrome, a novel, fatal, infectious disease of hibernating bats. Conservation Biology, vol. 25, no. 2, pp. 223-231. http://dx.doi.org/10.1111/j.1523-1739.2010.01638.x. PMid:21284732

FRICK, W.F., POLLOCK, J.F., HICKS, A.C., LANGWIG, K.E., REYNOLDS, D.S., TURNER, G.G., BUTCHKOSKI, C.M. 
and KUNZ, T.H., 2010. An emerging disease causes regional population collapse of a common North American bat species. Science, vol. 329, no. 5992, pp. 679-682. http://dx.doi.org/10.1126/ science.1188594. PMid:20689016.

FRISVAD, J.C., FRANK, J.M., HOUBRAKEN, J.A.M.P., KUIJPERS, A.F.A. and SAMSON, R.A., 2004. New ochratoxin A producing species of Aspergillus section Circumdati. Studies in Mycology, vol. 50, no. 1, pp. 23-43.

GANDRA, R.F., GAMBALE, W., DE CÁSSIA GARCIA SIMÃO, R., DA SILVA RUIZ, L., DURIGON, E.L., DE CAMARGO, L.M., GIUDICE, M.C., SANFILIPPO, L.F., DE ARAÚJO, J. and PAULA, C.R., 2008. Malassezia spp. in acoustic meatus of bats (Molossus molossus) of the Amazon Region, Brazil. Mycopathologia, vol. 165, no. 1, pp. 21-26. http://dx.doi.org/10.1007/s11046-0079079-7. PMid:18046623.

GREGORIN, R. and TADDEI, V.A., 2002. Chave artificial para a identificação de Molossideos brasileiros (Mammalia, Chiroptera). Mastozoología Neotropical, vol. 9, no. 1, pp. 13-32.

HEITMAN, J., 2011. Microbial pathogens in the fungal kingdom. Fungal Biology Reviews, vol. 25, no. 1, pp. 48-60. http://dx.doi. org/10.1016/j.fbr.2011.01.003. PMid:21528015.

HOLZ, P.H., LUMSDEN, L.F., MARENDA, M.S., BROWNING, G.F. and HUFSCHMID, J., 2018. Two subspecies of bent-winged bats (Miniopterus orianae bassanii and oceanensis) in southern Australia have diverse fungal skin flora but not Pseudogymnoascus destructans. PLoS One, vol. 13, no. 10, pp. 1-19. http://dx.doi. org/10.1371/journal.pone.0204282. PMid:30303979.

INSTITUTE OF MEDICINE - IOM, 2011. Fungal Diseases: An emerging threat to human, animal, and plant health. Washington, DC: The National Academic Press, 488 p.

INSTITUTO BRASILEIRO DE GEOGRAFIA E ESTATÍSTICA - IBGE, 2012 [viewed 11 December 2018]. Manual Técnico da Vegetação Brasileira [online]. $2^{\mathrm{a}}$ ed. Rio de Janeiro: Instituto Brasileiro de Geografia e Estatística, 275 p. Available from: http:// www.terrabrasilis.org.br/ecotecadigital/pdf/manual-tecnico-davegetacao-brasileira.pdf

JOHNSON, L.J., MILLER, A.N., MCCLEERY, R.A., MCCLANAHAN, R., KATH, J.A., LUESCHOW, S. and PORRAS-ALFARO, A., 2013. Psychrophilic and Psychrotolerant fungi on bats and the presence of Geomyces spp. on Bat wings prior to the arrival of white nose syndrome. Applied and Environmental Microbiology, vol. 79, no. 18, pp. 5465-5471. http://dx.doi.org/10.1128/ AEM.01429-13. PMid:23811520.

KALKO, E.K.V., 1998. Organisation and diversity of tropical bats communities through space and time. Zoology (Jena, Germany), vol. 101, no. 4, pp. 281-297.

KOKUREWICZ, T., OGÓREK, R., PUSZ, W. and MATKOWSKI, K., 2016. Bats increase the number of cultivable airborne fungi in the "Nietoperek" bat reserve in western Poland. Microbial Ecology, vol. 72, no. 1, pp. 36-48. http://dx.doi.org/10.1007/ s00248-016-0763-3. PMid:27084554.

KWON-CHUNG, K.J. and SUGUI, J.A., 2013. Aspergillus fumigatus - what makes the species a ubiquitous human fungal pathogen? PLoS Pathogens, vol. 9, no. 12, pp. 1-4. http://dx.doi. org/10.1371/journal.ppat.1003743. PMid:24348239.

MAIA, L.C., 2005. Fungos. In: K.C. PÔRTO, ed. Diversidade biológica e conservação da floresta atlântica ao norte do Rio São Francisco. Brasília, DF: Ministério do Meio Ambiente, Cap. 4, pp. 75-106.
MINNIS, A.M. and LINDNER, D.L., 2013. Phylogenetic evaluation of Geomyces and allies reveals no close relatives of Pseudogymnoascus destructans, comb. nov., in bat hibernacula of eastern North America. Fungal Biology, vol. 117, no. 9, pp. 638-649. http://dx.doi.org/10.1016/j.funbio.2013.07.001. PMid:24012303.

NELSON, P.E., TOUSSOUN, T.A. and MARASSAS, W.F.O., 1983. Fusarium species: an illustrated manual for identification. University Park, PA: The Pennsylvania State University Press, 193 p.

NOGUEIRA, M.R., LIMA, I.P., GARBINO, G.S.T., MORATELLI, R., TAVARES, V.C., GREGORIN, R. and PERACCHI, A.L., 2018 [viewed 1 January 2019]. Updated checklist of Brazilian bats: version 2018.1 [online]. Rio de Janeiro: CLMB, SBEQ. Available from: http://www.sbeq.net/updatelist

PASSOS, F.C., MIRANDA, J.M.D., BERNARDI, I.P., KAKUOLIVEIRA, N.Y. and MUNSTER, L.C., 2010. Morcegos da Região Sul do Brasil: análise comparativa da riqueza de espécies, novos registros e atualizações nomenclaturais (Mammalia, Chiroptera). Iheringia. Série Zoologia, vol. 100, no. 1, pp. 25-34. http://dx.doi. org/10.1590/S0073-47212010000100004.

PAZ, G.S., ADORNO, B.M.V., RICHINI-PEREIRA, V.B., BOSCO, S.M.G. and LANGONI, H., 2018. Infection by Histoplasma capsulatum, Cryptococcus spp. and Paracoccidioides brasiliensis in bats collected in urban areas. Transboundary and Emerging Diseases, vol. 65, no. 6, pp. 1797-1805. http://dx.doi.org/10.1111/ tbed.12955. PMid:30296014.

PERACCHI, A.L. and NOGUEIRA, M.R. 2010. Métodos de captura de quirópteros em áreas silvestres. In: N.R. REIS, A.L. PERACHI, B.K. ROSSANEIS, and M.N FREGONEZI, eds. Técnicas de estudos aplicadas aos mamiferos silvestres brasileiros. Rio de Janeiro: Technical Books, pp. 42-58.

PERFECT, J.R. and SCHELL, W.A., 1996. The New Fungal Opportunists Are Coming. Clinical Infectious Diseases, vol. 22, no. 2, suppl. 2, pp. 112-118. http://dx.doi.org/10.1093/clinids/22. Supplement_2.S112. PMid:8722837.

PITT, J.I., 1979. The genus Penicillium and its teleomorphics states Eupenicillium and Talaromyces. London: Academic Press, 634 p.

PITT, J.I. and HOCKING, A.D., 2009. Fungi and food spoilage. 3. ed. New York: Springer, 524 p. http://dx.doi.org/10.1007/9780-387-92207-2.

RAPER, K.B. and FENNEL, D.I., 1965. The genus Aspergillus. Baltimore, MD: The Williams and Wilkings, $686 \mathrm{p}$.

REIS, N., GALLO, P.H., PERACCHI, A.L., LIMA, I.P. and FREGONEZI, M.N., 2012. Sensitivity of population of bats (Mammalia: Chiroptera) in relation to human development in northern Paraná, Southern Brazil. Brazilian Journal of Biology = Revista Brasileira de Biologia, vol. 72, no. 3, pp. 511-518. http:// dx.doi.org/10.1590/S1519-69842012000300014. PMid:22990822.

REIS, N., PERACCHI, A., BATISTA, C., LIMA, I. and ALAN, P., 2017. História natural dos morcegos brasileiros: chave de identificação de espécies. Rio de Janeiro: Technical Books, 416 p.

SAMSON, R.A., HONG, S.B. and FRISVAD, J.C., 2006. Old and new concepts of species differentiation in Aspergillus. Medical Mycology, vol. 44, no. s1, suppl. 1, pp. 133-148. http://dx.doi. org/10.1080/13693780600913224. PMid:30408897.

SANTANA-NETO, P.L., ALBUQUERQUE, C.M.R., SILVA, A.P.P., SVEDESE, V.M. and LIMA, E.A.L.A., 2010. Natural occurrence of the Fusarium solani on Tityus stigmurus (Thorell, 1876) (Scorpiones: buthidae). Brazilian Journal of Biology $=$ 
Revista Brasileira de Biologia, vol. 70, no. 1, pp. 151-153. http:// dx.doi.org/10.1590/S1519-69842010000100021. PMid:20231972.

SEYEDMOUSAVI, S., GUILLOT, J., ARNÉ, P., DE HOOG, G.S., MOUTON, J.W., MELCHERS, W.J. and VERWEIJ, P.E., 2015. Aspergillus and aspergilloses in wild and domestic animals: A global health concern with parallels to human disease. Medical Mycology, vol. 53, no. 8, pp. 765-797. http://dx.doi.org/10.1093/ mmy/myv067. PMid:26316211.

SHAPIRO, J.T., SANTOS, T.M.R., MARCHETTI, C.R., LORENZLEMKE, A.P., DELARMELINA, E. and BORDIGNON, M.O., 2015. Characterization of fungi associated with the nasal hairs of Molossid bats. Fungal Ecology, vol. 18, pp. 126-129. http:// dx.doi.org/10.1016/j.funeco.2015.06.005.

SILVA, N., JUNQUEIRA, V.C.A., SILVEIRA, N.F.A., TANIWAKI, M.H., SANTOS, R.F.S. and GOMES, R.A.R., 2010. Manual de métodos de análise microbiológica de alimentos e água. 4th ed. São Paulo: Varela, 624 p.

SOUZA, D.A.S., 2011. Análise morfométrica de Molossus molossus (Chiroptera, Molossidae) ao longo de um gradiente latitudinal no Brasil. Porto Alegre: Instituto de Biociências, Universidade Federal do Rio Grande do Sul, 65 p. Dissertação de Mestrado em Biologia Animal.

TALAMONI, S.A., COELHO, D.A., DIAS-SILVA, L.H. and AMARAL, A.S., 2013. Bat assemblages in conservation areas of a metropolitan region in Southern Brazil, including an important karst habitat. Brazilian Journal of Biology $=$ Revista Brasileira de Biologia, vol. 73, no. 2, pp. 309-319. http://dx.doi.org/10.1590/ S1519-69842013000200011. PMid:23917558.

TAYLOR, M. and TUTTLE, M.D., 2019. Bats: An illustrated guide to all species. Smithsonian Books. $400 \mathrm{p}$
TENCATE, L.N., TÁPARO, C.V., CARVALHO, C., BOSCO, S.M.G., QUEIROZ, L.H., SILVA, D.C., PERRI, S.H.V. and MARINHO, M., 2012. Study of gastrointestinal fungal flora of bats (Mammalia, Chiroptera) of the northwest region of São Paulo state: zoonotic potential. Brazilian Journal of Veterinary Research and Animal Science, vol. 49, no. 2, pp. 146-152. http:// dx.doi.org/10.11606/issn.2318-3659.v49i2p146-152.

TORTORA, G.J., FUNKE, B.R. and CASE, C.L., 2012. Microbiologia. 10. ed. Porto Alegre: Artmed, 967 p.

TURNER, G.G., REEDER, D.M. and COLEMAN, J.T.H., 2011. A five-year assessment of mortality and geographic spread of white-nose syndrome in North American bats and a look to the future. Bat Research News, vol. 52, no. 5, pp. 13-27.

VOYRON, S., LAZZARI, A., RICCUCCI, M., CALVANI, M. and VARESE, G.C., 2011. First mycological investigations on italian bats. Hystrix: The Italian Journal of Mammalogy, vol. 22, no. 1, pp. 189-197. http://dx.doi.org/10.4404/Hystrix-22.1-4481.

WEBER, M.M., RAMON, C. and CÁCERES, N.C., 2013. Mamíferos do Rio Grande do Sul. Santa Maria: UFSM, 554 p.

WOOLHOUSE, M.E.J. and GOWTAGE-SEQUERIA, S., 2005. Host range and emerging and reemerging pathogens. Emerging Infectious Diseases, vol. 11, no. 12, pp. 1842-1847. http://dx.doi. org/10.3201/eid1112.050997. PMid:16485468.

YADAV, A.N., VERMA, P., KUMAR, V., SANGWAN, P., MISHRA, S., PANJIAR, N., GUPTA, V.K. and SAXENA, A.K., 2018. Biodiversity of the genus Penicillium in different habitats. In: V.K. GUPTA and S. RODRIGUEZ-COUTO. New and future developments in microbial biotechnology and bioengineering. Amsterdam: Elsevier, pp. 3-18. https://doi.org/10.1016/B9780-444-63501-3.00001-6. 